\title{
Small Forensic "Smart-Law-Scripts" the First Step for Intelligent Justice Punishment in Law Enforcement, Economic Crime and Alternative Sentences
}

\author{
Kanavas Vasilios \\ Law Faculty, Aristoteles University of Thessaloniki \\ Egnatia 156, Thessaloniki 546 21, Thessaloniki, Ellas, Greece

\begin{abstract}
Zisopoulos Athanasios
Faculty of Mathematics and Informatics, University of Sofia Saint Kliment Ochridsky

Blvd "James Bourchier" 5, 1164 g.k. Lozenets, Sofia, Bulgaria
\end{abstract}

Stamatis Papangelou

${ }^{3}$ Department of Economics, University of Macedonia

Egnatia 156, 54636 Thessaloniki, Ellas, Greece

Received: April 2, 2018 Accepted: April 17, 2018 Published: April 23, 2018

doi:10.5296/ber.v8i2.13045 URL: https://doi.org/10.5296/ber.v8i2.13045

\begin{abstract}
In our research we introduce "the forensic smart contract" as a punishment alternative for tiny law violations. After studied the legislation boundaries and legal power transfer example for out of court applications, we evaluated three Blockchain applications covering three various cases in smart contracting. A smart-Law-script to eliminate illegal cellphone car use, with best punishment an Irrevocable prepayment in digi-money for a car phone kit. Then a "Lawscript" resolving the double taxation problem in international tax conventions. Finally a Court launches a community sentence through a "Rehabilitation Law sentence script". After mass adoption of our methodologies we faced an unexpected globalization peace factor in Blockchain and much wide adoption of CBDC (Central Bank Digital Currency).
\end{abstract}

Keywords: Fintech, Regtech, Lawtech, smart contracts, Ethereum, Tax Law, Mathematical Programming, community sentence, Blockchain 


\section{1) Macrothink}

\section{Journal of Economic Literature (JEL) Codes:}

C00 Mathematical and Quantitative Methods, C15 Statistical Simulation Methods, C63 Computational Techniques; Simulation Modeling, C65 Miscellaneous Mathematical Tools, E59 Monetary Policy- Central Banking, H26 Tax Evasion, K00 Law and Economics, K12 Contract Law, K 14 Criminal Law, K20 Regulation and Business Law, K 21 Antitrust Law, K29 Regulation and Business Law, K34 Tax Law, K36 Family and Personal Law.

\section{Introduction}

An automatic police and law enforcement is a very old concept, older than the world itself. The most important and old reference was by Evangelist John in his Gospel concerning the final judgment:

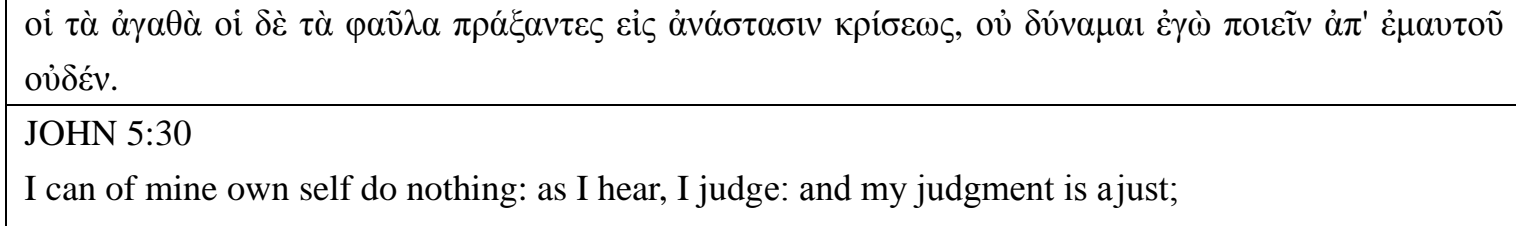

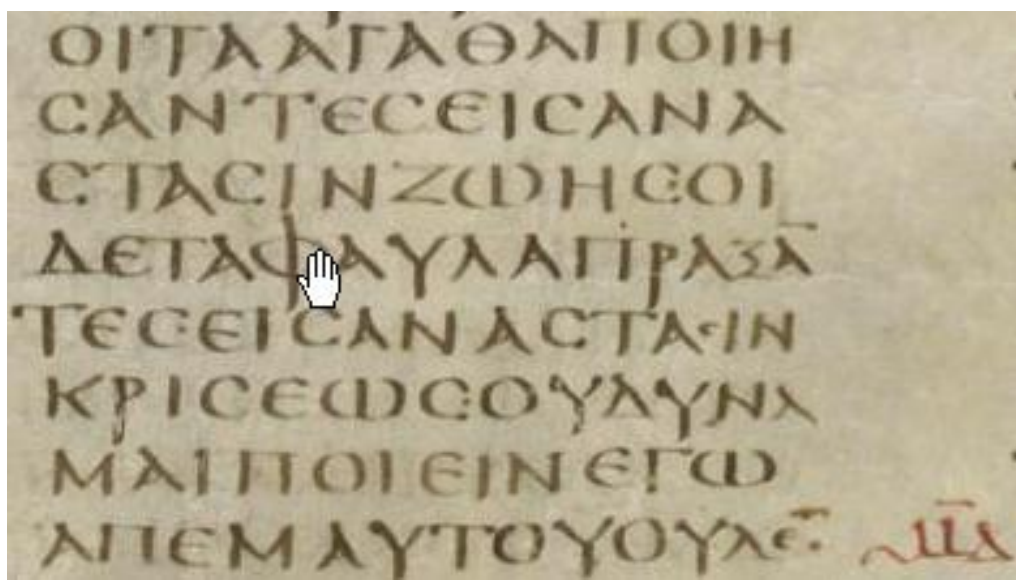

Figure 1, The most ancient lawtech script (Codex Sinaiticus)

The above Scriptura describes the most important moment of the life of every human being. In front of God every sinner waits the sentence of his evil life. In the Christian literature most of the times the forgiveness plays the main role. But not today, here at the final stage of all humanity no mercy seems to be possible, it occurred in all previous of soul and life stages.

In the first ever "smart law" Jesus clearly statuses that even God cannot do anything else than to apply pure Law. Just and Judgment are referred here in order to explain in exact words that there is a Law and no one can violate the Law, even the Son of GOD.

The biggest problem of forensic automated punishments is altogether the only benefit:

ONCE LAUNCHED cannot be recalled or Cancelled

On the current Law side, they are very suspicious to transfer Constitutional power to unstable entities. An example is out-of-court debt settlement mechanism. It introduced for the first time in the Greek legal system by Law 4469/2017. This mechanism aims to protect viable 
businesses and constitutes an organized out-of-court process for final settlement of debts payable to the private and public sector by Greek businesses, for debts accumulated up to 31 December 2016. The companies that regards the mechanism are separated to the "big ones" when they have operation's circle over 2.500 .000 euro or over 2.000 .000 euro overdue obligations and the "small ones" in any other occasion

Use of experts and technological means, the organization of all stages of the process within reasonable deadlines, as well as the contribution and flexibility of the Greek State as a creditor are the cornerstones to this new mechanism.

When and if the involved parties come to agreement they still have the right to seek ratification of the debt settlement agreement by the court, if they wish, so that non-contracting creditors would also be bound by the agreement.

More than 2700 companies and 7000 freelancers have applied for inclusion in an online platform for the out-of-court debt settlement mechanism in the first few days after the official launch of the platform, according to the data from the platform's operation. This probably sounds ideal but the applications that have been completed are only 700 and from them 23 have positive conclusion. According to estimates of Economy ministry, 150,000 to 400,000 enterprises could participate in the mechanism and that kind of numbers, given the current efficiency of the mechanism, sounds alarming. The real question here is why something so beneficial for enterprises must be so hard to be accomplished. Greece after so many years of recession and reforms must find a way to limit bureaucracy. Also the European institutions must decide faster the mix of the economic measures that to be applied to Greek economy.

The mechanism will contribute to the unsecured debts of the state, social insurance funds and will especially help the banks that have binding targets for a significant reduction of their non-performing exposures. This of course will happen only if all related parties find a way to simplify the procedure and the European comity not to interfere again like happened before.

\section{Guidelines, Assumptions}

Our third pylon of our constitutional system suffers from a lot of irregularities like human mercy, society anger, political assumptions, legislation proliferation and inaccuracy, not real independence and a lot of others. If there is a change in a million for automatic sentencing, we have to give a try.

General Blockchain and digital law research do not realize the expanded dimensions and the future of Blockchain (Levy 2017, DuPont 2015, Maupin 2017, Trautman 2016, De Filippi 2018, Rodrigues 2018 and Guggenberger 2017).

In our times blockchain was evolved in a technology for every aspect of economic life. In very small timeframe the suffix "tech" has been attached to all sciences to form a "scientific superiority with technicality". Such new terms are: FinTech financial technology

The tech suffix actually implements any aspect of life in computer technology, but a computer is not alone. Every single PC and software incorporates Algorithms, Statistics, Operational Research, math modelling, artificial intelligence, man-machine interaction theory, 
and hundreds of sciences included Law Sciences. For the purpose of our law enforcement research we use similar terms:

- Banktech, banking technology for clever payment options.

- Fintech, financial technology.

- Insurtech, where insurance agencies demand smaller premium charges.

- LawTech, technology that facilitates-enables Legislation application.

- RegTech ; regulations technology to manage Governance, risk and compliance.

\subsection{Smart Contract}

Traditionally digital forensics evolves day by day in a crucial economic fraud fighting tools. Usually digital forensic supports the police and justice in all court tasks. In our sentencing example Rose (1997) gave Community Sentences new value, while Byrne (2010) examined the use of community-based sentencing options within federal sentencing guidelines and specific recommendations and finally Schild (2005) Cantrell (2012) and Koopmans (2013) investigate the computer as a digital expert system.

The best smart contract description was given by replacing the God from USD motto (Simser 2015). Of course God initially was away of money but the phrase "In Code we trust" denotes the exact situation. For this study for an Ethereum Smart Contract in programming language Solidity-Lisp we use the terms:

- Smart contract is the basic program usually running in Github

- "LawTech Script" contains legislation logic along with contracting guidelines.

- "rehabilitation law script" is close to our approach to improve the citizen through the legal system not to punish him.

- "Sentence script" needs very careful design because it affects irrevocably people life.

Along with others we also hope 'smart' contracts have been around for a long time - we at least try not to write dumb ones (Giancaspo 2017). For this research we studied and analyzed with minor success: smart contract terminology (Mik 2017), technical side of the law (Simpson-Murphy 2016), various legal issues associated with the application of existing contract law provisions implemented on the Blockchain platform (Simpson 2016), the internal side of the law (Giancaspro 2017), block chain for justice (Mariana 2016) and a new concept of rule technologies (Marino 2016)

\subsection{CBDC (Central Bank Digital Currencies)}

At current tempo spatial frame Legislative Authorities, Courts, Lawyers and almost the majority of citizens are not aware of blockchain money.

Being at the legitimate side of legal order we need a more concrete digital coin like CBDC (Central Bank Digital Currency). According to a recent BIS internal paper (Bank of International Settlements, Bech 2017) new cryptocurrencies are emerging twice a day. Central banks expected to issue their own with different characteristics and from existing payment options. They called it $\mathrm{CBCC}$ where $\mathrm{CC}$ is standing for crypto currencies but bank cannot be evolved in nothing Crypto. Though this study the term CBDC is used as identical 
to the Cryptocurrency, Bitcoin, Ether and blockchain money. We contribute to law blockchain with 3 descriptive low level case studies:

- Lawscript to deteriorate illegal cellphone car use.

- Double taxation avoidance law script

- In front of Court Rehabilitation Law sentence script

The story telling intentionally kept verbal in order to avoid technicalities in the blockchain world where this approach is trivial.

\section{Lawscript to Deteriorate Illegal Cellphone Car Use}

Hundreds of researchers studied the effect of mobile phone in driving performance (Lesch 2004, Tornros 2005, Strayer 2006). Others they focus on the police and legislation actions to be taken to eliminate cell phone use.

We do not believe in the famous tyrant Drakon Law enforcement principles and we developed a light voluntary participation to demonstrate police action. According to our counter-Drakon approach and researchers like Treffner (2004), White (2010) and Cohen (2005). We came to the conclusion that the best punishment for illegal cell-phone use while driving is to install a car cell phone installation. The phone user automatically is charged on the benefit of car installation company with an amount to be collected immediately from the telephone provider or the Blockchain account.

\subsection{Traffic Incident Lawtech Smartscript}

However, there are others more traditional punishment approaches. Until today the traffic policeman stops a cell-phone user and an endless discussion starts with confiscation, anger and all human limitations become present. Due to this old fashioned incident we lose a lot of money and we waste precious human energy and effort in the road and later on court. We propose a "Lawtech SmartScript" to take care all of these.

In the new era again the policeman stops the cell phone user. The driver faces two options: the traditional and the automatic. In automatic mode he dials in from his cellphone under the policeman supervision a police-court authorized number and everything finished. Then the convicted driver first reaction is to drive away from police "brutality" while the second is to call his friends to chat about the event of the day, starting all over new violations and possible accidents. Well no more.

The telephone number is the primary input of the first "traffic law tech script". A SOLIDITY smart contract is executed automatically. The script was prepared by the traffic police under special legislation and lies in the Blockchain as higher level anonymous agency. Script authority is so neutral as any court designed it to be. As every program has three phases: Input, Process and Output.

The unique input is the telephone number to be dialed in.

The process runs a random number generator very often in Blockchain with an exact syntax: 
Menu_selection_num=keccak256(bitcoinBlockHash);

Then the value Menu_selection_num is transliterated in a random number from 1 to 8 . Then according to this random number the "Lawscript" outputs to the telephone company Blockchain the selected function. Immediate punishment list could include:

- Block the phone for 24 hours, starting NOW.

- Block the phone for 20 days starting tomorrow.

- Block the phone for 10 days and pay now 20 Euro.

- Limit call duration to 30 Seconds for 20 days starting now.

- Block outgoing SMSs for two months

- Irrevocably sending an engagement prepayment in digi-money from phone company or offender bitcoin account to a company installing car phone kit.

\subsection{Legislation Drawback}

The key issue for the policeman in the above example is to obtain the driver cellphone number to enforce the "law-script" penalty. A recent USA Law case has proven this legal (US vs Place 1983) clearly stated that: "Where law enforcement authorities have probable cause to believe that a container holds contraband or evidence of a crime but have not secured a warrant the Court has interpreted the [Fourth] Amendment to permit seizure of the property"

However recently there are other law interpretations primarily in the United states (Ohie vs Smith 2009) that reduces the police power: "Once the cell phone is in police custody the state has satisfied its immediate interest in collecting and preserving evidence and can take preventive steps to ensure that the data found on the phone are neither lost nor erased. But because a person has a high expectation of privacy in a cell phone's contents police must then obtain a warrant before intruding into the phone's contents."

It is obvious that currently legislator is not ready for complicated contracts like the proposed one. We believe that for many years from now the above "rehabilitation incident" it will be only "LawTech script" in a voluntary basis.

\section{Double Taxation Avoidance Law Script}

Tax agencies in Greece deal very often with double taxation problems. The first signed convention was signed 1953 between the Kingdom of Greece (1963) and the United States of America for the avoidance of double taxation and the prevention of fiscal evasion with respect to taxes on income. (Barcleys 1994). Since then a lot of billions are lost for Greek IRS and today we assembled the table covering a few aspects of tax evasion of wealthy persons. The table below is the tax evasion tool of risk Greeks living abroad. For Greeks according to the table England is the Business and money tax paradise.

Table 1. Greece double taxation smart contract table

\begin{tabular}{|l|l|l|l|l|}
\hline country & legislation & dividends & interest & Royalties \\
\hline England & $2732 / 1953$ & $10 \%$ & $0 \%$ & $0 \%$ \\
\hline Germany & $52 / 1967$ & $25 \%$ & $10 \%$ & $0 \%$ \\
\hline
\end{tabular}




\begin{tabular}{|l|l|l|l|l|}
\hline Switzerland & $1502 / 1984$ & $15 \%$ & $10 \%$ & $5 \%$ \\
\hline Bulgaria & $2255 / 1994$ & $40 \%$ & $10 \%$ & $10 \%$ \\
\hline USA & $2548 / 1953$ & $10 \%$ & $15 \%$ & $20 \%$ \\
\hline
\end{tabular}

Rich monopolies do not rely on the above tax evasion but they do concoct legal cases to further postpone any tax payment. Due to the complexity of EU tax systems usually they do succeed. Politicians, accountants, public servants, professors and endless chain of "professionals" a whole mechanism it works for them. A solution to break the chain-ties of tax evasion and not encouraging the excessive litigation would be the "blockchain LawTech script". To assembly the state service is very complicated but once set it works efficiently. The generalized pseudocode law-script does the following:

- The blockchain of the airport arrivals triggers every time a Greek Passenger living abroad.

- The triggering enables a blockchain that collects data according to the bilateral convention between beneficiary countries.

- The table above is compared to the local Greek table and a fine is executed.

- The Greek Tax Authority collects the fine immediately if there is a CBDC account or even a crypto currency account declared.

- An additional $20 \%$ tax exemption could be applied.

The airport terminal confronts a demonstration entity. A simple bank transfer could do the same results along another equally simple action: the foreign country tax blockchain. This tax blockchain is an irrevocable database of the tax payer that cannot be altered by any power or authority of a sovereign country. This is a good question to the blockchain community, what will happen in case of a local or worldwide war conflict?

The past century money laundering was a rich oligarchs privilege. Last decade BIS, FED, IMF and ECB attempted to deteriorate anonymous untaxed money with significant results. The unreasonable low tax countries are obligated to sign the above mentioned "double taxing conventions. Therefore, a recursion will eventually occur where the "double tax conventions" for a tax blockchain will affect the convention and all over again.

\section{In front of Court Rehabilitation Law Sentence Script}

Older researcher focus on behavioral rehabilitation (Allen 2000) and even recent books do not cover technology (Craig 2013). The evidences and economic analysis approach (Weisburd 2017) are more close to our semi-automatic law script intentions. When someone is sentenced, they can get one of four main types of sentence:

- discharge

- fine

- community sentence

- prison sentence

\subsection{Community Sentences}

Initially Drakon inspired the law principles (Ogden 2013) line and later Omalley (1999) 
suggested of a more draconian system of punishment. They both belong to archaic societies. Today British ministry of Justice (2018) proposes various type of rehabilitation punishments.

Table 2. Community payback sentences rehabilitation results

\begin{tabular}{|l|l|l|}
\hline Community payback Sentences & $\begin{array}{l}\text { Computer Aided } \\
\text { rehabilitation }\end{array}$ & $\begin{array}{l}\text { IDENTITY } \\
\text { recognition }\end{array}$ \\
\hline carry out between 40 and 300 hours unpaid work as 'Community Payback'; & $10 \%$ & 5 \\
\hline get training so they can find a job & $5 \%$ & 5 \\
\hline $\begin{array}{l}\text { complete a treatment program - to deal with anger control, drug or alcohol } \\
\text { abuse, for example avoid specific activities, like visiting pubs or football } \\
\text { matches }\end{array}$ & $80 \%$ & $100 \%$ \\
\hline $\begin{array}{l}\text { live within a curfew that restricts the times they can leave their homes, } \\
\text { monitored by wearing an electronic tag }\end{array}$ & $100 \%$ & $20 \%$ \\
\hline $\begin{array}{l}\text { live at a specific place } \\
\text { get mental health treatment, if they agree }\end{array}$ & $100 \%$ & $20 \%$ \\
\hline have regular meetings with a probation officer to check their progress & $5 \%$ & $80 \%$ \\
\hline $\begin{array}{l}\text { go to an attendance center, where } 18 \text { to } 24 \text { year-olds take part in group } \\
\text { activities to help them live responsibly in the community }\end{array}$ & $1 \%$ & $100 \%$ \\
\hline
\end{tabular}

The percentage next to every sentence denotes:

- Computer Aided rehabilitation percentage gives methodology success rating.

- IDENTITY recognition is the positive absolute personal recognition

Unfortunately, these wise "community payback" sentences belong to a generation without digital media. The biggest problem to enable digitally the rehabilitation procedure is exactly this identity theft. The problem is more crucial in machine enabled rehabilitation because it concerns persons with intensive criminal-like behavior. Their primary nature is to cheat and society has to prepare bullet proof systems for all low level community sentences.

\subsection{Blockchain Based Asynchronous Rehabilitation Reading and Test}

We transformed the above "treatment program" into an easy multimedia training course with specifications like:

- Rehabilitation Video-Audio clips running under software control.

- Programmable interrupts with various questions to be answered from the keyboard.

- A session recording system registering all DAV (Data_audio_video) elements

- Various ID recognition systems.

A similar system is tailored to prepare a "traders workstation" based on "financial time series" conducted research (Gerakis 2016) and a patent (Zisopoulos 2017). The timeline is like this:

- Magistrate or Judger convicts a traffic light offender into a community sentence to a treated cure for the driver to improve attitude and knowledge of traffic law.

- The conviction is described in a smart contract.

- The offender finds an appropriate device (DAV netPC) and he runs the program. 
- He sees the video improving his society understanding.

- After an hour or a minute, the video stops and the computer demands an answer.

- The operator keys in the answer or selects a quiz option.

- The whole session is recorded in DAV and two files are stored in the computer under the name: "session1-Zisopoulos.dav" with the session recordings and a simple text file with answer sequence.

- The offender connects to a site and the files are hashing irrevocably by the Ethereum Blockchain locally WITHOUT to actual file transfer.

- End of lesson ONE, 100 more to follow.

The court decision "smart contract" is executed once per day and when the counter. The major problem here is identity theft. Natawiguna (2016) proposed virtualization methods for securing online exams from cheating with tools that can be used to enhance the existing proctoring methods used for securing online exam with better process isolation and low bandwidth usage. There are other more complicated methods to verify identity. We only present a simple low blockchain level solution to demonstrate the "rehabilitation law script".

This education-rehabilitation technology is very useful in war refugees total rehabilitation. They are very committed in technology and western societies legal civilization cannot face them a priori guilty of something they do not understand at the desired level.

\section{Results}

The adoption of court decided "automated law scripts" like any human arrangement has significant virtuous and evil results. Significant results for the progression of the society are:

- The court focus on progressive work, not with simple repetitive costly nonsense hearings, session and la over again the same.

- The law script denotes an opportunity to chain archaic origination of the Roman Law, still in use in our days.

- The code is the law and it is executed without human intervention.

- No Hacking is possible; this is the computer of the future.

There are also bad to catastrophic results:

- IT concerns a major threat to the humanity with all these robots controlling real people life.

- The court could never be satisfied from a "law script" since usually their technology knowledge and the level needed is not adequate.

- Eventually the blockchain one day will fail. We all remember the Ethereum fork (Dickerson 2017, Atzei 2017)

\section{Discussion}

There are severe problems to solve and additional systems to be prepared in order to present to the science and society a viable alternative "law script". There are unlimited complications to overcome. 


\section{Macrothink

During our research we faced the globalization problem and peace element in Blockchain words. Turkish empire tries to invade once more Cyprus. Apparently Israel an England help the Cypriots. Before the conflict Cyprus (the promised Blockchain land) has a lot of cryptocurrency contracts. These smart scripts increasingly support local and worldwide business. During the crisis the brave Cypriots along with Russian help they resist to the invade. Half hemisphere is involved in the conflict and we finally have war. Who fight whom is not discussed here, we only arise a simple question:

What will be happen to the Blockchain contracts?

By design these are irrevocable actions and they cannot be recalled even in order to serve the country honor or existence. In some way they must stop, they are not accepted by national effort. The answer is obvious: Peace is a side effect of ledger expansion.

\section{Conclusion}

We hope that we do not violate two French contributions to the world as we know it.

First Montesquieu in his famous articulation of the theory of the separation of powers «in every government there are three sorts of power: the legislative; the executive in respect to things dependent on the law of nations; and the executive in regard to matters that depend on the civil law.» (Montesquieu 1949).

Although full three powers isolation was not always clear combination is something totally different. There are a lot of different nature institutions thereafter, on of these could be smart law scripts.

\section{Acknowledgements}

Initially I, Athanasios Zisopoulos, thank the only person in the world that supported my initial effort: Dikaios Tserkezos from University of Crete.

We thank our professors from Aristoteles University of Thessaloniki under Saint Dimitrios blessing and Sofia University under Saint Clementios Ochridksi blessing.

Finally we thank Sir Iraklis Mavromatidis for his everlasting support of our preliminary research ideas and his effort to convert them into society progression.

\section{References}

Allen, R. (2000). Putting the community back into community sentences. Criminal Justice Matters, 39(1), 4-4. https://doi.org/10.1080/09627250008552833

Atzei, N., Bartoletti, M., \& Cimoli, T. (2017, April). A survey of attacks on Ethereum smart contracts (SoK). In International Conference on Principles of Security and Trust (pp. 164-186). Springer, Berlin, Heidelberg. https://doi.org/10.1007/978-3-662-54455-6_8

Barclays Bank PLC v. Franchise Tax Bd. of Cal., 512 U.S. 298, 114 S. Ct. 2268, 129 L. Ed. 2d 244 (1994).

Bech, Morten L. and Garratt, Rodney, (2017). Central Bank Cryptocurrencies BIS Quarterly 
Review September 2017. Available at SSRN: https://ssrn.com/abstract=3041906

Byrne, J. M., \& S. Turner (2010). Reforming Federal Sentencing Guidelines: A Modest Proposal. Victims \& Offenders, 5(3), 220-232. https://doi.org/10.1080/15564886.2010.485976

Cantrell, G., Dampier, D., Dandass, Y. S., Niu, N., \& Bogen, C. (2012). Research toward a partially-automated, and crime specific digital triage process model. Computer and Information Science, 5(2), 29. http://dx.doi.org/10.5539/cis.v5n2p29

Codex Sinaiticus, the British Library, Leipzig University Library, St Catherine's Monaster at Sinai and the National Library of Russia (exactly as accesed in Feb 2018 http://www.codexsinaiticus.org/en/manuscript.aspx ?book=36\&chapter=5\&lid=en \&side=r\&v erse $=29 \&$ zoomSlider $=0$

Cohen, D. J. (2005). The Cambridge companion to ancient Greek law. Cambridge University Press.

Craig, L. A., Gannon, T. A., \& Dixon, L. (Eds.). (2013). What works in offender rehabilitation: An evidence-based approach to assessment and treatment. John Wiley \& Sons. https://doi.org/10.1002/9781118320655

De Filippi, P., \& Hassan, S. (2018). Blockchain technology as a regulatory technology: From code is law to law is code. arXiv preprint arXiv:1801.02507.

Dickerson, T., Gazzillo, P., Herlihy, M., \& Koskinen, E. (2017, July). Adding concurrency to smart contracts. In Proceedings of the ACM Symposium on Principles of Distributed Computing (pp. 303-312). ACM. https://doi.org/10.1145/3087801.3087835.

DuPont, Q., \& Maurer, B. (2015). Ledgers and Law in the Blockchain. Kings Review (23 June 2015)

http://kingsreview.co.uk/magazine/blog/2015/06/23/ledgers-and-law-in-the-blockchain

Gerakis G, Dimitrios Razis, \& Athanasios Zisopoulos, (2016). NICODIMUS, a forensic device to support Avocate and Judger public function and office, International Symposium on Ambient Intelligence and Embedded Systems,AmiEs 2016 Proceedings,Heraklion, Crete, Greece, 22 - 24 September, 2016,

Giancaspro, M. (2017). Is a 'smart contract' really a smart idea? Insights from a legal perspective. Computer Law \& Security Review, 33(6), 825-835.

https://doi.org/10.1016/j.clsr.2017.05.007

Guggenberger, N. (2017). The Potential of Blockchain Technology for the Conclusion of Contracts. Contracts for the Supply of Digital Content: Regulatory Challenges and Gaps: Münster Colloquia on EU Law and the Digital Economy II. R. Schulze, D. Staudenmayer and S. Lohsse. Baden-Baden, Nomos Verlagsgesellschaft mbH \& Co. KG: 83-98. https://doi.org/10.5771/9783845281391-83

Jeffrey Simser (2015). Bitcoin and modern alchemy: in code we trust, Journal of Financial Crime, 22(2), 156-169, https://doi.org/10.1108/JFC-11-2013-0067 


\section{Macrothink}

Business and Economic Research ISSN 2162-4860 2018, Vol. 8, No. 2

Kõlvart, M., Poola, M., \& Rull, A. (2016) Smart Contracts. In: Kerikmäe T., Rull A. (eds) The Future of Law and eTechnologies. Springer, Cham https://doi.org/10.1007/978-3-319-26896-5_7

Koopmans, M. B., \& James, J. I. (2013). Automated network triage. Digital Investigation, 10(2), 129-137. https://doi.org/10.1016/j.diin.2013.03.002

Lesch, M. F., \& Hancock, P. A. (2004). Driving performance during concurrent cell-phone use: are drivers aware of their performance decrements?. Accident Analysis \& Prevention, 36(3), 471-480. https://doi.org/10.1016/S0001-4575(03)00042-3

Levy, K. E. (2017). Book-smart, not street-smart: blockchain-based smart contracts and the social workings of law. Engaging Science, Technology, and Society, 3, 1-15.

https://doi.org/10.17351/ests2017.107

Marianna Papadakis, 'Blockchain's Big Opportunity for Lawyers' (Financial Review, 2 June 2016).

http://www.afr.com/business/legal/blockchains-big-opportunity-for-lawyers-20160531-gp82p2

Marino B., \& Juels, A. (2016) Setting Standards for Altering and Undoing Smart Contracts. In: Alferes J., Bertossi L., Governatori G., Fodor P., Roman D. (eds) Rule Technologies. Research, Tools, and Applications. RuleML 2016. Lecture Notes in Computer Science, vol 9718. Springer, Cham https://doi.org/10.1007/978-3-319-42019-6_10

Maupin, J. (2017). The G20 countries should engage with blockchain technologies to build an inclusive, transparent, and accountable digital economy for all (No. 2017-48). Economics Discussion Papers. http://hdl.handle.net/10419/163569

Mik, E. (2017). Smart contracts: terminology, technical limitations and real world complexity. Law, Innovation and Technology, 9(2), 269-300.

https://doi.org/10.1080/17579961.2017.1378468

Ministry of Justice, http://open.justice.gov.uk/how-it-works/sentencing-and-rehabilitation/ (access date 20 March 2018)

Montesquieu. (1949). The Spirit of the Laws (No. 9). Simon and Schuster.

Natawiguna, A., \& Liem, M. M. I. (2016). Virtualization methods for securing online exam. 2016 International Conference on Data and Software Engineering (ICoDSE).

https://doi.org/10.1109/ICODSE.2016.7936145

Ogden, D. (2013). Drakon: Dragon Myth and Serpent Cult in the Greek and Roman Worlds. Oxford University Press. https://doi.org/10.1093/acprof:oso/9780199557325.001.0001

O'MALLEY, P. A. T. (1999). Volatile and contradictory punishment. Theoretical Criminology, 3(2), 175-196. https://doi.org/10.1177/1362480699003002003

Rodrigues, Usha, Law and the Blockchain (February 21, 2018). University of Georgia School of Law Legal Studies Research Paper No. 2017-07. Available at SSRN:

https://ssrn.com/abstract=3127782 


\section{Macrothink}

Business and Economic Research ISSN 2162-4860 2018, Vol. 8, No. 2

Rose, C. (1997). Electronic Monitoring of Offenders: A New Dimension in Community Sentencing or a Needless Diversion? International Review of Law, Computers \& Technology, 11(1), 147-154. https://doi.org/10.1080/13600869755884

Schild, U. J., \& R. Kannai (2005). Intelligent Computer Evaluation of Offender'sPrevious Record. Artificial Intelligence and Law, 13(3), 373-405.

https://doi.org/10.1007/s10506-005-5793-y

Simpson, B. (2016). Algorithms or advocacy: does the legal profession have a future in a digital world? Information \& Communications Technology Law, 25(1), 50-61. https://doi.org/10.1080/13600834.2015.1134144

Simpson, B. and M. Murphy (2016). Technological challenges and opportunities: the future of law. Information \& Communications Technology Law, 25(1), 1-3.

https://doi.org/10.1080/13600834.2015.1134145

State v. Smith, 124 Ohio St. 3d 163, 2009 Ohio 6426, 920 N.E.2d 949 (2009).

Strayer, D. L., Drews, F. A., \& Crouch, D. J. (2006). A comparison of the cell phone driver and the drunk driver. Human factors, 48(2), 381-391.

https://doi.org/10.1518/001872006777724471

Törnros, J. E., \& Bolling, A. K. (2005). Mobile phone use-effects of handheld and handsfree phones on driving performance. Accident Analysis \& Prevention, 37(5), 902-909. https://doi.org/10.1016/j.aap.2005.04.007

Trautman, Lawrence J., (2016), Is Disruptive Blockchain Technology the Future of Financial Services?. The Consumer Finance Law Quarterly Report, 232(2016). Available at SSRN: https://ssrn.com/abstract=2786186

Treffner, P. J., \& Barrett, R. (2004). Hands-free mobile phone speech while driving degrades coordination and control. Transportation Research Part F: Traffic Psychology and Behaviour, 7(4-5), 229-246. https://doi.org/10.1016/j.trf.2004.09.002

United States v. Place, 462 U.S. 696, 103 S. Ct. 2637, 77 L. Ed. 2d 110 (1983).

Weisburd, D., Farrington, D. P., \& Gill, C. (2017). What Works in Crime Prevention and Rehabilitation. Criminology \& Public Policy, 16(2), 300-317.

https://doi.org/10.1111/1745-9133.12298

White, K. M., Hyde, M. K., Walsh, S. P., \& Watson, B. (2010). Mobile phone use while driving: An investigation of the beliefs influencing drivers' hands-free and hand-held mobile phone use. Transportation Research Part F: Traffic Psychology and Behaviour, 13(1), 9-20. https://doi.org/10.1016/j.trf.2009.09.004

ZISOPOULOS, GR20160100277, General Purpose Recording Device To Embed Forensics Accepted Digital Certificates To The Internet Distributed Art, Communication And Politics Multimedia Products, ZISOPOULOS Athanasios, priority date:"27/5/2016",creation:"12/01/2017" 


\section{Copyright Disclaimer}

Copyright for this article is retained by the author(s), with first publication rights granted to the journal.

This is an open-access article distributed under the terms and conditions of the Creative Commons Attribution license (http://creativecommons.org/licenses/by/3.0/). 